\title{
Gender-based variations in the perception of climate change impact, vulnerability and adaptation strategies in the Pra River Basin of Ghana
}

\author{
Enoch Bessah, AbdulGaniy Olayinka Raji, \\ Olalekan John Taiwo, Sampson Kwaku Agodzo, \\ Olusola Oluwayemisi Ololade, Alexandre Strapasson and \\ Emmanuel Donkor \\ (Author affiliations can be found at the end of the article)
}

Perception of climate change impact

\begin{abstract}
Purpose - This study aims to assess gender-based differences on farmers' perception of impacts and vulnerability to climate change and the implementation of adaptation strategies in the Pra River Basin of Ghana, while also providing lessons for other Sub-Saharan nations and regions with similar conditions.

Design/methodology/approach - The study used semi-structured interviews and questionnaires to collect data from 344 farmers, 64 participants in focus group discussions and 6 agriculture extension officers (key informants) from 10 districts in the Pra River Basin of Ghana.

Findings - Results showed several differences in how climate change is perceived and tackled by male and female genders. In the perception of male farmers, for example, they were found to be more vulnerable to increased temperature, and changes in rainfall and growing season, whereas female farmers on average were considered to be less resilient to floods and droughts for different reasons. Moreover, floods posed higher risks to farming than other climate change impacts. Gender roles had a significant correlation with the type of adaptation strategies practised. Men adopted agrochemicals more often than women, as an adaptation strategy.
\end{abstract}

(C) Enoch Bessah, AbdulGaniy Olayinka Raji, Olalekan John Taiwo, Sampson Kwaku Agodzo, Olusola Oluwayemisi Ololade, Alexandre Strapasson and Emmanuel Donkor. Published by Emerald Publishing Limited. This article is published under the Creative Commons Attribution (CC BY 4.0) licence. Anyone may reproduce, distribute, translate and create derivative works of this article (for both commercial and non-commercial purposes), subject to full attribution to the original publication and authors. The full terms of this licence may be seen at http://creativecommons.org/licences/by/4.0/ legalcode

This paper was prepared based on the $\mathrm{PhD}$ thesis submitted by the first author to the Pan African University Institute of Life and Earth Sciences at the University of Ibadan, Nigeria and funded by the African Union Commission. The research was supported by the International Foundation for Science, Stockholm, Sweden, through a grant to Enoch Bessah [grant W_6201-1] and by the International Support Network for African Development (ISNAD-Africa). We acknowledge the farmers, Directors of the Department of Agriculture and Extension Officers from the 10 districts involved in this study. Moreover, we thank Imperial College London for making this publication available in open access possible. A., Strapasson also thanks Henry Lee from Harvard's Belfer Center for his continuous support. Finally, we appreciate the professional work done by the editor and the anonymous reviewers to improve the quality of this paper.
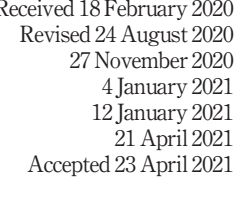
IJCCSM

$13,4 / 5$

Research limitations/implications - Gender-differentiated interventions should be incorporated in the national climate change action plan for sustainable development in a rain-fed agricultural economy such as Ghana. The study recommends several actions to promote gender equity in the assessed region.

Originality/value - This research assessed the gender differentials in climate trends, impact, vulnerability and adaptation based on primary data collected between April and May 2019 and compared the results with climate data in the basin for the period 1991-2014. It is an empirical study focused on primary data analysis obtained in loco by authors, involving approximately 400 participants.

Keywords Adaptation, Agriculture, Climate change impact, Gender equality, Ghana, Sub-Saharan Africa, Vulnerability

Paper type Research paper

\section{Introduction}

The interplay between climate change, gender equality and agricultural development has received growing attention in the scientific community, governments and non-governmental agencies. This relationship is important for agricultural-based economies in Africa, with limited resources for climate change adaptation. Existing studies show that climate change negatively affects crop production (Xu et al., 2019; Chandio et al., 2020) and household food security, especially in rural communities with limited adaptation capacity (Wossen et al., 2018). The impacts of climate change may be more adverse on small communities highly dependent on the use of natural resources as their main source of income (Lobell et al., 2008). Although climate change is expected to have major impacts on a global scale, the rural population in the tropics is more vulnerable to climate change (IPCC, 2007, 2014). Some of the impacts of climate change include increased morbidity and mortality (Gasparrini et al., 2017), decreased labour productivity and supply, decreased economic output (Wossen et al., 2018), mass migration (Hsiang and Sobel, 2016), lower human capital (Garg et al., 2018), reduced working hours (Masuda et al., 2019) and extreme climate events (IPCC, 2014; Traore et al., 2020).

Africa has been experiencing extreme climate events and would, therefore, need external support to reduce its possible devastating effects in the future (New et al., 2006; Niang et al., 2014; Traore et al., 2020). Agriculture in Africa uses 65\% of the labour force and contributes $32 \%$ to the gross domestic product (GDP) of the continent (Chauvin et al., 2012). This sector is strongly climate-dependent, making it more susceptible to the effects of global warming. Some of the risks climate change poses to agriculture are increased frequency of droughts and floods (Chhogyel and Kumar, 2018) and severity of pests and disease outbreaks (Shikuku et al., 2017) resulting in market shocks (Lobell et al., 2008). The lack of technology access, stable political system and diversification in the economic industry for the masses, threaten the sustainability of the region, especially the rural poor. The use of irrigation, for example, is still an emerging technology in Sub-Saharan African countries. Evidence shows that the adoption rate of irrigation technology was $6 \%$ as of 2010 in Africa and $4 \%$ in SubSaharan Africa as compared to $28 \%$ in Northern Africa (IFPRI, 2010). Moreover, the percentage of women who have been reported to be more vulnerable to climate change accounts for about $80 \%$ of climate vulnerability in Africa's agricultural sector (Denton, 2002).

Ghana Statistical Services (GSS) (2013) reported that 45.8\% of households countrywide were involved in agriculture with $95.1 \%$ involved in crop farming. It was also found that men accounted for $71.3 \%$ of the total labour directly with agricultural activities. This result must be seen in context because women represent more than half $(52 \%)$ of the labour force in Ghana, contributing to $46 \%$ of the GDP (MEST, 2012). Moreover, women are often subject to a double burden, working to earn money while also being responsible for a significant 
workload of domestic unpaid labour (Hooks, 2014). Hence, the variation in gender cannot be overlooked when assessing climate impact, vulnerability and adaptation strategies for the purpose of developing relevant policies to improve the agricultural sector. Several studies have reported women as being the most vulnerable gender to climate change (Alhassan et al., 2019; Lawson et al., 2019; Yadav and Lal, 2018). However, variations in location, culture and climatic conditions call for site-specific investigation in Africa due to its diverse nature for specific policy interventions.

Access to resources and information has been found to influence adaptation capacity to climate change of which access to education (Ojo and Baiyegunhi, 2020), land and credit (Below et al., 2012; Ahmed et al., 2016) are the leading three factors in Africa. Gender-based adaptation is location-specific and sector biased (Codjoe et al., 2012). Understanding the local perspective of climate adaptation would help in the decisionmaking on what and where to implement certain interventions in terms of infrastructure and strategies (MEST, 2012; Owusu et al., 2018). It is evident that climate change will slow down the achievement of sustainable development goals due to the demands it poses on gender equality. Sex-disaggregated information is required in developing gender-sensitive policies and programme to enhance sustainable livelihoods in the face of climate change. For instance, drought resulting from climate change will increase the distance to be covered in search of water and fuel wood for both domestic use and farming which is mostly the role of young girls and women in most parts of Africa (UNDP, 2011). However, there is a lack of this type of disaggregated information and consistent case-study assessment such as for the Pra River Basin, which plays a key role in Ghana's agricultural development.

Therefore, the objective of this study was to assess how the different perceptions of male and female farmers on climate change impacts influence their vulnerability status and adaptation strategies in the Pra River Basin of Ghana, to inform public policies and sustainable investments in the region, as a case-study on climate-agriculture-gender nexus in Sub-Saharan Africa. In this paper, the term gender is defined by the roles, identities, norms, responsibilities, relations and opportunities constructed to a group by society (WHO, 2011). Inequality is determined by the society in the way one is treated especially women and not based on biological factors (UNDP, 2010). Understanding these socially constructed differences in relation to climate change ensures that some of the disproportionately in the distribution of interventions are reduced for equitable adaptation.

\section{Methodology}

The research was prepared with a focus on technical analysis of primary and secondary data, especially on the relationship between gender and climate change adaptation in rural communities, rather than an epistemological discussion on gender equality, feminism and agricultural development more broadly, which are equally important, but was not the objective of this study. Moreover, the aim of this study was not to discuss the sociohistorical aspect related to gender discrimination, violence against women, transgender issues, personal beliefs and cultural values. The study focuses on different perspectives of male and female farmers regarding climate change impact, vulnerability and adaptation at the local level. It also offers a technical contribution on climateagriculture-gender nexus, based on original data collected in loco by the first author, involving approximately 400 participants and literature review, which were then assessed in collaboration with his co-authors, using different statistical methods, as described in the following sections. 
IJCCSM

$13,4 / 5$

\section{8}

Figure 1.

Map of Pra River Basin showing (a) spatially random sampled district for questionnaire administration, (b) mean annual rainfall distribution for the period 1981-2010 and (c) digital elevation model [NB:

Population density was obtained from 2010 population and housing census in Ghana (GSS, 2013)]

\subsection{Study area}

The study was carried out in the Pra River Basin in Ghana (Figure 1). This basin presents the highest dense settlement in the nation and the majority of the inhabitants are farmers (WRC, 2012). The climatic and agro-ecological zones in the basin are suitable for agriculture (Dickson and Benneh, 1995). Land use activities within the basin are very intense as both legal and illegal mining competes with agriculture for space and natural resources due to its suitable elevation [Figure 1(c)]. Illegal mining is also known as galamsey in the local language, a term used in this study for accuracy reasons. The basin contains most of the large cocoa growing areas in the Eastern, Ashanti and Central Regions of Ghana. Cocoa followed by oil palm are the major tree crops cultivated and of recent rubber, the plantation was introduced through the planting for food and jobs project by the Government of Ghana (MoFA, 2017). Food cropping has increasingly been commercialized with the study area currently the highest spot for the production of tuber crops in Ghana (Nutsukpo et al., 2013; Kusimi et al., 2015).

The basin experiences two rainfall seasons annually, with an average annual amount of 1,446 mm (Bessah et al., 2020a). The major and minor rainfall seasons occur between March/ April and July and between September and October/November, respectively, while the dry season is from November to March. The lowest and highest mean temperatures annually were $25^{\circ} \mathrm{C}$ and $28^{\circ} \mathrm{C}$, respectively (Bessah et al., 2018). Climate change has resulted in delayed onset of rainfall and prolonged dry spells that resulted in decreased agriculture productivity (Bessah et al., 2020a). In addition, there has been the frequent occurrence of floods and inter-seasonal droughts which is a signal of climate change impacts, although the basin experiences two rainfall seasons in a year (WRC, 2012). The continuous changes in the onset of rainfall and its increased intensity, which often results in floods, are of major concern in Ghana, as the basin is a major producer of crops with high economic value, not to

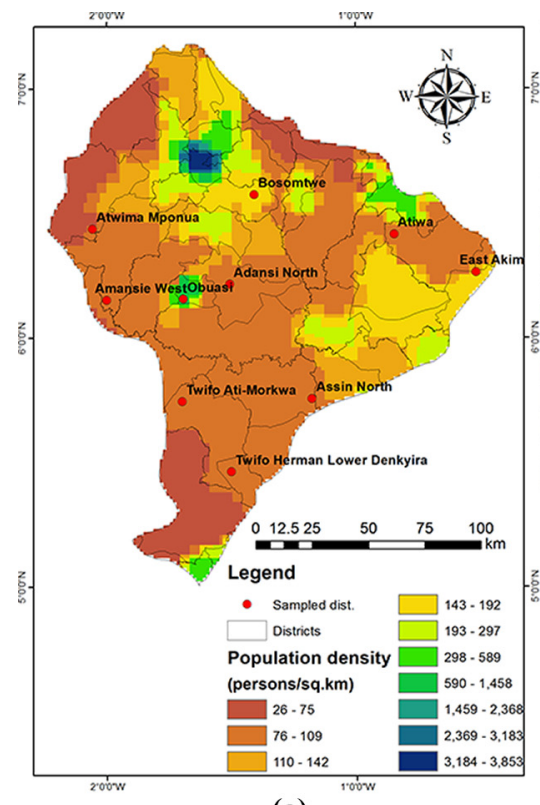

(a)

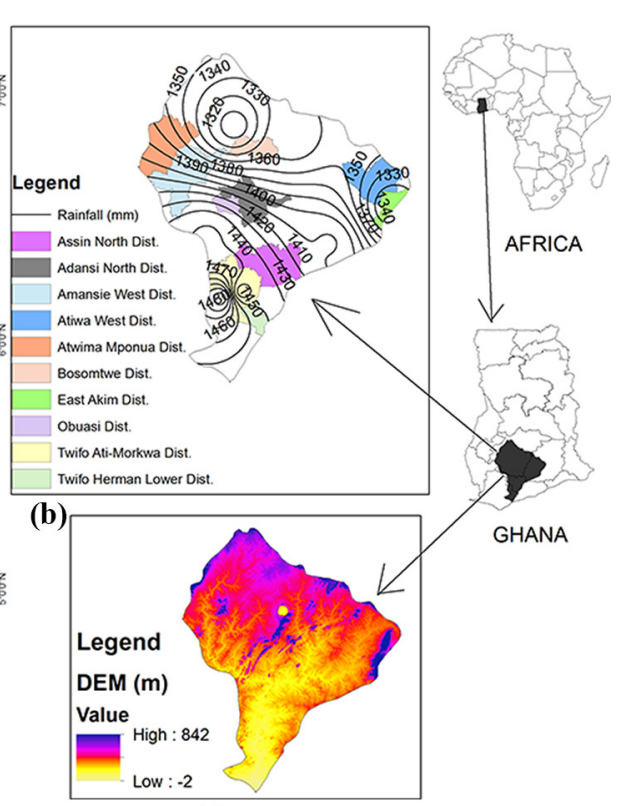

(c) 
mention several social and environmental impacts caused by these changes (Nutsukpo et al., 2013).

\subsection{Sampling and data collection techniques}

Three levels of sampling were done in this study. Firstly, spatial random sampling was done in ArcGIS 10.3 using the random point generation technique to select 10 districts in the Pra River Basin. Five of the districts fell within the Ashanti region (Amansie West, Atwima Mponua, Bosomtwe and Adansi North (now Adansi Asokwa) and Obuasi (now Obuasi East)); three were within the Central region (Assin North, Twifo Ati Morkwa and Twifo Heman Lower Denkyira) and the remaining two districts in the Eastern region (Atiwa and East Akim which are now called Atiwa West and Abuakwa South, respectively) of Ghana as already shown in Figure 1.

In the second level of sampling, three communities located along rivers in each district were purposely selected according to their proximity to riverbanks. This was done to assess the impact of climate change on both rainfall and dry season cropping. Research has shown that limited access to water is a hindrance to climate change adaptation especially in the mono-modal climate (Savannah agro-ecological) zones of Ghana (Fagariba et al., 2018).

Regarding the third (and final) level of sampling, respondents were randomly sampled for the questionnaire administration, although the focus was to increase female participation at all locations. This was necessary due to the limited representation of women in such gatherings (community or training) which might be attributed to culture and historical reasons in Ghana (Nyantakyi-Frimpong and Bezner-Kerr, 2015). The triangulation (mixed) method was used for the data collection. That is semi-structured interviews (farmers), key informant interviews (with agriculture extension officers) and focused group discussions (FGDs). FGDs were made up of about eight persons in each district comprising of extension officer(s), leaders of farmers association, community leaders and key farmers appointed by participants in the study locations. This method was used to ensure the accuracy of the information gathered from the respondents. All farmers who participated in this study have voluntarily identified themselves either as men or women, apart from other possible gender identities. Their respective names were kept anonymous. In total, approximately 400 people were involved in the study, being 344 local farmers, 22 extension officers and other participants such as policymakers at the community level.

\subsection{Data collection instruments and approach}

The Yamane simplified formula for proportions was adopted to determine the number of respondents (farmers) to interview (Singh and Masuku, 2014). The total population of crop farming households in the 10 districts was 165,195 inhabitants from the 2010 population census (GSS, 2013). The determined sample size from Taro Yamane's (1967) simplified formula of proportion for precision (e) $\pm 5 \%$ was 399 . This was similar to a sample size of 400 for a population above 100,000 according to Glenn (1992). In total, 14 respondents (household heads) were randomly sampled from each of the three communities purposely selected based on their location. Four communities were not accessible during the survey period due to flooded roads during the data collection period.

A total of 344 respondents were interviewed from the 10 districts in the months of April and May 2019. Out of the total respondents, $70.1 \%$ were men $(n=241)$ and $29.9 \%$ were women $(n=103)$, although the survey application targeted to involve as many women as possible. A questionnaire with both open and closed-ended questions was structured into four sections from A to D with each section capturing socio-economic characteristics, awareness and perception of climate change, farmers' adaptation options and support for
Perception of climate change impact 
IJCCSM

$13,4 / 5$

farmers' adaptation measures, respectively. The questions were structured in this manner to help understand how the activities of the farmers including their livelihood are shaped by their perception of climate change and adaptation strategies. The language used for the questionnaire administration was Twi [1]. The questionnaire was pretested at Barekese, in the Atwima Nwabiagya district of the Ashanti Region. A total of 12 households were interviewed during the pre-test and the outcome was used to restructure the questionnaire to the current format used for this study.

FGDs were organized in nine districts with a total of 64 participants (male $=75 \%$; female $=$ $25 \%$ ). Each FGD per district involved about six to eight persons, as recommended by Manoranjitham and Jacob (2007). FGDs participants comprise chief farmers (appointed chair of farmers' in a community), agriculture extension officers and at least one farmer representative from the three communities surveyed in each district. The same discussion guide extracted from the administered questionnaire was used in all districts during FGDs in the Twi language. The discussions were recorded and transcribed for anonymous qualitative analysis.

A total of 22 extension officers $($ men $=81.8 \%$, women $=18.2 \%$ ) were involved in the whole study. The ratio confirms the male dominance and gender inequality in the skilled agriculture sector, as similarly observed in Ghana's national census (GSS, 2013). A selfadministered in-depth questionnaire (in the English language) following the same sections and questions for the farmers were used to collect key informant data from agriculture extension officers with one extension officer representing each district. Out of a total of 10 questionnaires administered to participating districts, six were returned for analysis. Questionnaires used for the study are available in the supplementary material.

\subsection{Climate data sources}

Daily rainfall, maximum and minimum temperature data were acquired from the Ghana Meteorological Agency (GMet) for the period 1991-2014 from seven functional climate stations (Kumasi, Akim Oda, Twifo Praso, Konongo, Dunkwa, Kibi and Atieku) within the Pra River Basin. Details of the climate stations are presented in previous studies by Bessah et al. $(2018,2020 \mathrm{a})$.

\subsection{Data analysis}

The questionnaire data were coded directly into IBM Statistical Package for Social Sciences (SPSS) version 21 for collation and analyses. Descriptive summaries were presented using graphs and frequency distribution tables. Chi-square was used to test the significance of variance between gender (male and female) on assessed variables at a $p$-value $<0.05$. The word-based technique was used to generate themes from responses during the FGDs and open-ended questions and then coded for simple ranking according to count analysis (Ololade and Rametse, 2018).

Climate data were processed with PivotTables in Microsoft Excel 2016 and trends presented in graphs. Rainfall analysis was based on the total rainfall amount obtained by summing up temporal (daily) rainfalls, whereas temperature analysis was based on its mean value. The major rainfall season analysis covered the period from March to July while the minor rainfall season covered September to November. Rainfall onset and cessation were determined with the modified Walter-Olaniran method used in Bessah et al. (2020a).

\section{Results}

The results cover the background of respondents, farmers and station observed trends of climate parameters, climate change impacts and adopted adaptation strategies of respondents. 


\subsection{Socio-economic characteristics of respondents}

Table 1 shows the descriptive statistics of the socio-economic characteristics of the respondents. Majority of the respondents constituting of men (76.3\%) and women $(75.7 \%)$ were between the ages of 30 and 60 years old. Men had, on average, more access to formal education and, had a higher literacy level. However, the highest level of education for the majority of both genders was Junior High School (JHS), which is, about nine years of formal education. More men had a household size (number of persons living together in a single house) of below 10 persons while more women had a household size above 10 persons. Men also had more access to social amenities than their female counterparts (Table 1).

Farming was the primary occupation for both men and women in the assessed areas, whereas trading was the highest secondary occupation, engaged by about half of the women (Table 1). The occupational distribution shows that women are more engaged in general activities and multiple livelihoods. This could be due to the family demands, considering their household size, number of children, lower access to formal education (on average), gender discrimination, among other reasons (Table 1).

Most men had their farm located either near a river or on a lowland compared to women. Even in a situation that the farm belongs to the same family, men usually choose the stated location and allocated other places to their spouses. This could be due to the fact that men in most cases decide the farm locations and had more control over resources than women. The most practised farming system was perennial cropping (cocoa) followed by crop rotation. Women had the highest representation for all types of cultivated crops (Table 1). The farm sizes attributed to men were above 10 acres, $(1$ acre $=0.4047 \mathrm{ha})$, while most of the women were below 10 acres (Table 1). These values represent an average; although sometimes couples and family members prepare farmland together, then demarcation is done immediately after planting.

Results from key informant interviews showed that the mean age and period of service of engaged extension officers (five men, one woman) were 40 years old and 11 years, respectively. Five had completed tertiary education while one had graduated from Senior High School. Participants of the FGDs were from the same group of respondents (extension officers and farmers) and are expected to have similar socio-economic characteristics as described in Table 1.

\subsection{Climate parameters based on farmers' and climate station observations}

Farmers' observations were based on the perception survey whereas climate station records were obtained from functional stations of the Ghana Meteorological Agency (GMet) in the basin.

3.2.1 Farmers' awareness of climate change and observed trends of climate parameters. Respondents' awareness of climate change and its impact on the basin were $99.2 \%$ and $96.1 \%$ for men and women, respectively. The main sources of awareness about climate change were through the radio followed by farmers' own experiences and television. Other minor information sources were friends/family, extension officers, mobile (App and SMS) and the internet (Figure 2).

Most farmers indicated that temperature has increased, rainfall amount has decreased, with varying trends of decline in water availability in the growing season (Figure 3), in the past two decades. More men observed these trends, although both gender groups agreed to this pattern of change. All the FGDs participants agreed with these observations and the interviewed extension officers. Three major causes of climate change as identified during the FGDs were deforestation, urbanization and small-scale illegal mining (galamsey).

\section{Perception of climate change impact}


IJCCSM

$13,4 / 5$

Characteristics

$\operatorname{Men}(\%, n=241)$

Women $(\%, n=103)$

Age (years)

Below 30

30-60

Above 60

5.4

76.3

18.3

15.7

Marital status (\%)

442

Single

8.7

87.1

Divorced

Widowed

2.5

1.7

Highest educational level

No formal

8.7

Primary

JHS

SHS

Tertiary

13.3

63.1

10.4

4.1

Access to social amenities

Electricity

Pipe borne water

Tarred roads

91.3

9.1

33.2

Easy transport to market

77.2

Health post

Primary school

JHS

43.2

85.1

83.0

SHS

10.8

22.3

Farm size (acres)

Below 5

5-10

16.6

48.5

11-20

Above 20

27.8

6.6

3.9

74.8

4.9

16.5

Number of children (count)

5 and below

54.8

35.7

6-10

3.7

31.1

19.4

44.7

1.9

2.9

Above 10

30.3

82.5

Household size (count)

5 and below

58.9

5.8

26.2

69.9

35.0

74.8

71.8

6-10

11-20

Above 20

10.4

0.4

6.8

Primary occupation

Farming

Trading

Professional/services

95.4

25.2

56.3

15.5

2.9

Secondary occupation

Farming

Trading

Table 1.

Professional/services

4.6

13.7

55.3

36.9

4.9

29.1

56.3

13.6

1.0

0.4

97.1

3.7

2.9

0

Location of farm

Socio-economic and farming

Near river

characteristics of

On a hill/slope

60.2

48.5 


Characteristics

Lowland/valley

Farming system

Shifting cultivation

Crop rotation

Perennial cropping

Type of crops

Vegetables

Cereals

Tuber/roots

Tree crops
$\operatorname{Men}(\%, n=241)$

39.0

16.6

57.7

88.4

41.5

81.7

89.6

97.5
Perception of climate change

40.8

26.2

63.1

77.7

58.3

88.3

95.1

100

Note: "JHS - Junior high school; SHS - Senior high school

Table 1.

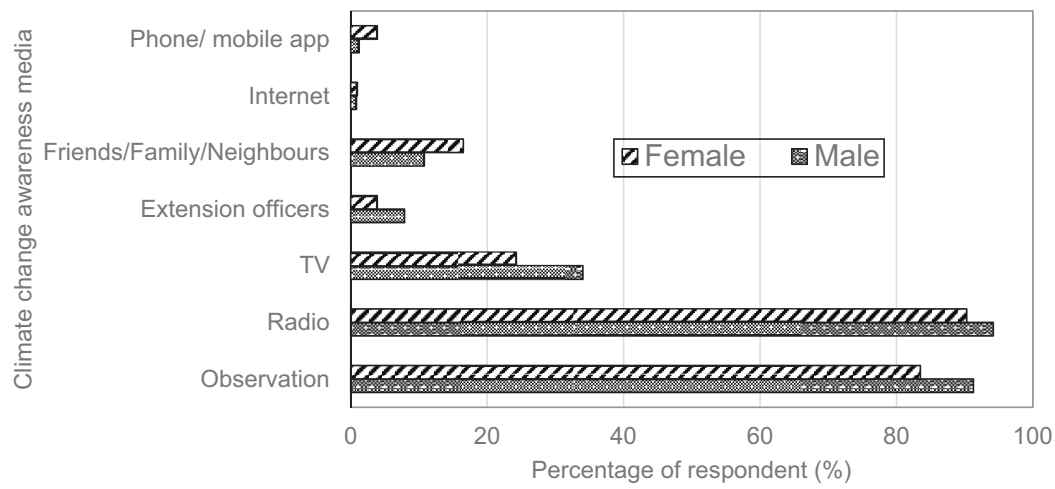

Figure 2.

Source of information pertaining to farmers' awareness of climate change in the Pra River Basin

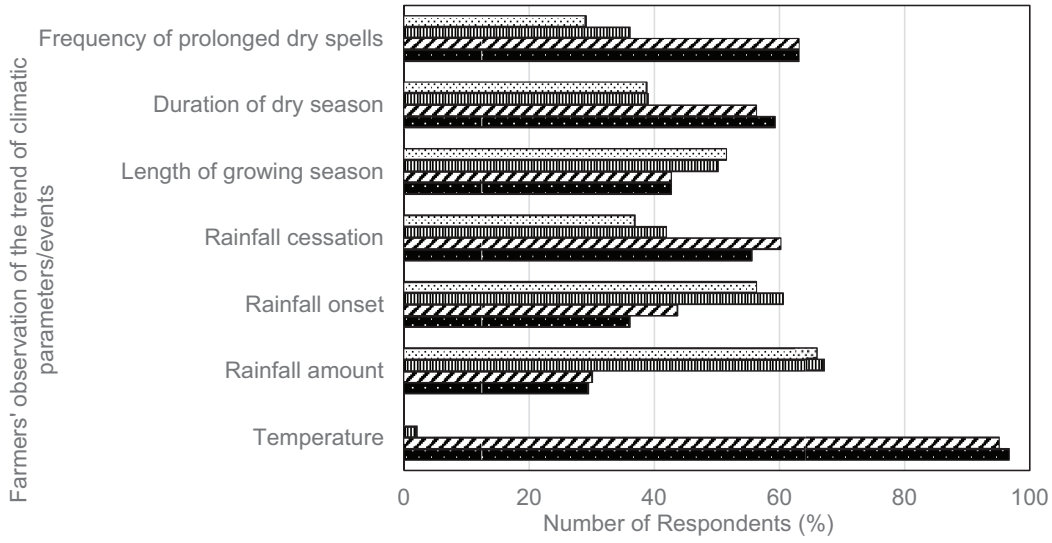

…Decrease/late (Female) mDecrease/late (Male) $\boldsymbol{\square}$ Increase/Early (Female) $\mathbf{m}$ Increase/Early (Male)

Figure 3.

Farmers' observed trends of climatic parameters/events of the past 20 years in the Pra River Basin 
IJCCSM

$13,4 / 5$

\section{4}

Figure 4.

Trend of the mean annual, major season and minor season rainfall amount observed at climate stations (1991-2014) in the Pra River Basin
3.2.2 Climate station observed records of rainfall and temperature. The mean annual, major rainfall (depth) season (March - July) and minor rainfall season (September - November) for the period 1991-2014 were 1,462 mm, $834 \mathrm{~mm}$ and $412 \mathrm{~mm}$, respectively (Figure 4). Rainfall amounts at all assessed levels showed an increasing trend. The maximum annual of $1,720 \mathrm{~mm}$ was recorded in 2014 whereas maximum rainfall for the major season $(1,045 \mathrm{~mm})$ was recorded in 2002 and that of the minor season $(664 \mathrm{~mm})$ was recorded in 2007 . The linear regression shows approximate trends with low coefficients of determination $\left(R^{2}\right)$, given the pseudo-chaotic oscillation pattern around the respective regression lines, as also presented in Figure 4. The linear regression was used to show the trend of the overall period of assessment recognizing that there would be a significant increase and decrease within the decades. The result $\left(R^{2}\right)$ also demonstrates the high variability of rainfall distribution over the seasons annually.

Results from the climate station during the observed period showed that early rainfall onset was on 20th January 2014 and late-onset was on 20th March 1992 and early and late cessation dates were 27th October 1991 and 29th December 2014, respectively (Figure 5). The rainfall onset had a decreasing trend, that is, onset was becoming early over the observed period while cessation showed an increasing trend (Figure 5). Maximum and minimum temperature also showed an increasing trend in the basin with mean maximum and minimum temperature of $31.72^{\circ} \mathrm{C}$ and $21.97^{\circ} \mathrm{C}$, respectively. Moreover, the minimum temperature was increasing slightly faster (slope of the line $=0.038 ; R^{2}=0.5483$ ) than maximum temperature (slope of the line $=0.025 ; R^{2}=0.4913$ ), although with a minor variation in the basin for the assessed period.

\subsection{Farmers' perceived climate change impact and vulnerability}

Climate change impact means assessed events in this study that were already affecting respondents farming activities negatively while the vulnerability was limited to climate events that could easily affect their activities.

3.3.1 Perception of climate change impacts. On a five-level Likert scale, the impact of climate change was perceived to be extremely severe by both genders. The three most common observed impact was the prevalence of pest invasion, the rising cost of agricultural inputs (such as fertilizers, agro-chemicals and seeds) and changes in the onset and cessation of rainfall (Table 2).

Men perceived the impact of climate change to be more extreme than their female counterparts. The severity of the impact was also confirmed during the FGDs to be extreme.

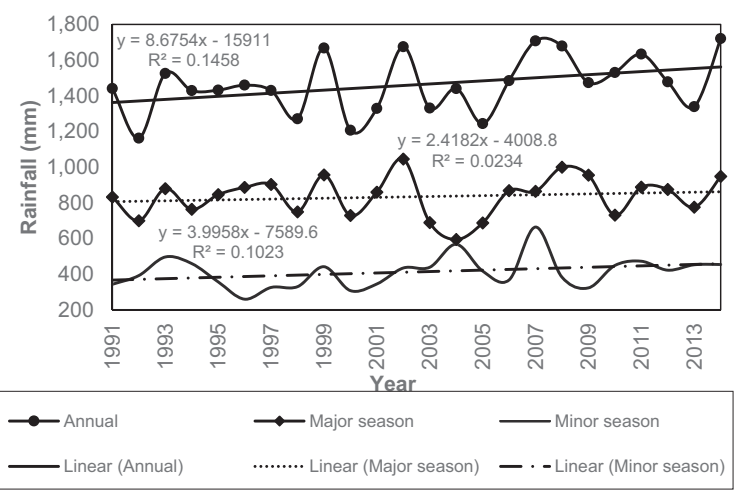




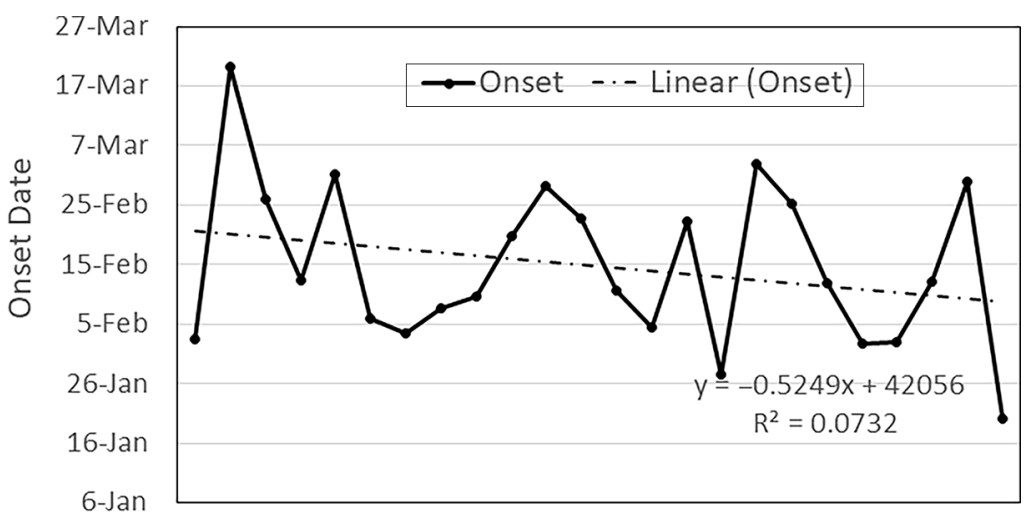

Perception of climate change impact
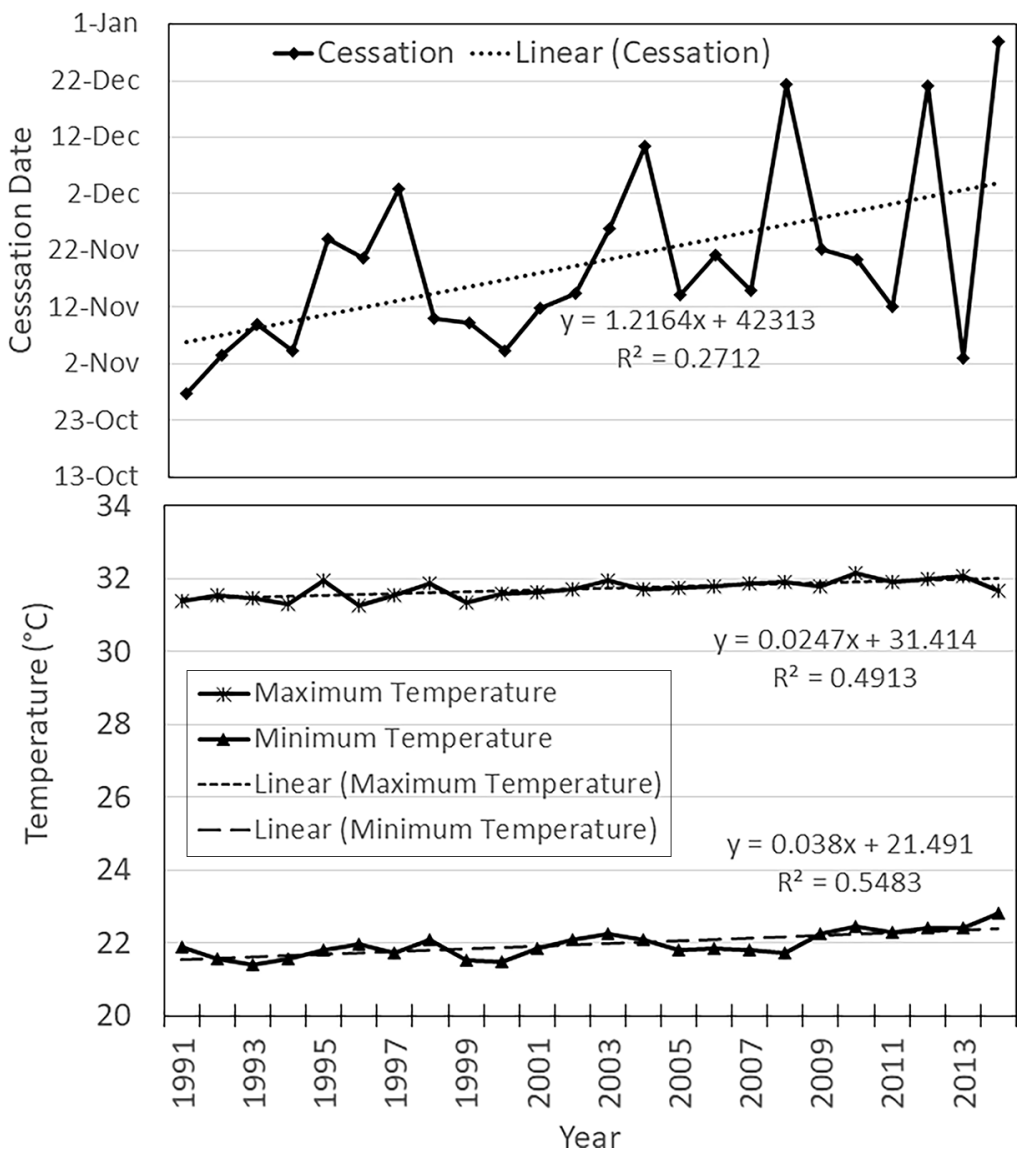

Figure 5.

Trend of rainfall onset and cessation dates, minimum and maximum temperature from observed climate station records (19912014) in the Pra River Basin 
IJCCSM

$13,4 / 5$

446
Table 2.

The perceived extent of climate change impact on resources and events over the past 20 years by respondents

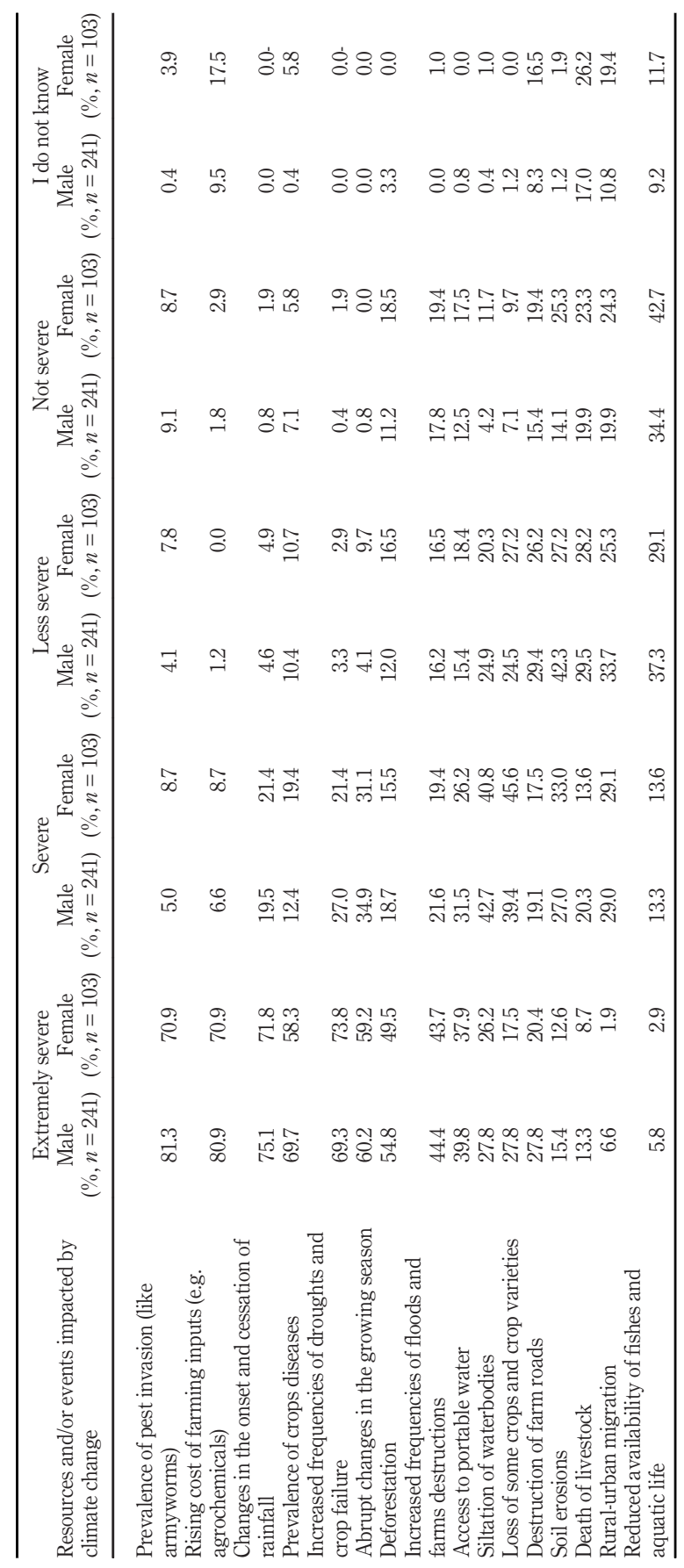


A comment from a male farmer from Akwaduroso in the Atiwa West district support this finding:

Climate change has made farming difficult these days. Sunshine during the dry season is too harsh that it destroys our crops especially transplanted cocoa and vegetable seedlings. Eventually, when it rains, the intensity is too high that it carries the young crops away. For instance, due to harsh weather in 2018, I could not get any harvest (zero) from my cocoa during the dry season.

Perception of climate change impact

A female farmer in the same FGDs also stated that:

The landowner of my cocoa farm has threatened to take away the land from me because for the past two years (2017 and 2018) almost all the transplanting I did to replace old cocoa trees died because of harsh weather.

These negative impacts of climate were reported in almost all the assessed districts by both men and women. The extension officers agreed with farmers on the severity of these impacts. However, they stated that it was severe and not extreme, which is aligned closer to female perceptions than male farmers. The difference in the perceived severity of impact could be due to the fact that farmers bear the repercussions of the negative impacts of climate in their activities and ascribed a weighting description to it based on the degree of their losses. The extension officers' perceptions, however, are based on information received from farmers and personal observations during field visits.

3.3.2 Perception of farmers' level of vulnerability. The findings presented in Figure 6 indicate that most farmers were experiencing extreme heat whereas very few of them indicated that flooding affected their farming activities. Both genders are vulnerable to the different categories of climate impact. In all the climate events except for floods and drought, where the percentage of men who are vulnerable tends to be higher than their female counterparts. From the focus group discussions, farmers and extension officers had a consensus that drought had a more devastating impact on their activities compared to flooding.

In terms of the impacts of flooding, farmers revealed that flooding hinders their access to farms and harvested crops for days and sometimes weeks. Most farmers especially women having their farms near rivers and low lands suffer crop loss during the minor season due to unforeseen pluvial floods as the first rains pour in February/March. When there is an overflow of rivers, men often try to cross them by either swimming or using a canoe, which most women are not comfortable with. All farms located near main rivers such as Birim, Offin, Gyimi, Oda and Pra suffer from flooding each year; which poses a high hazard to the

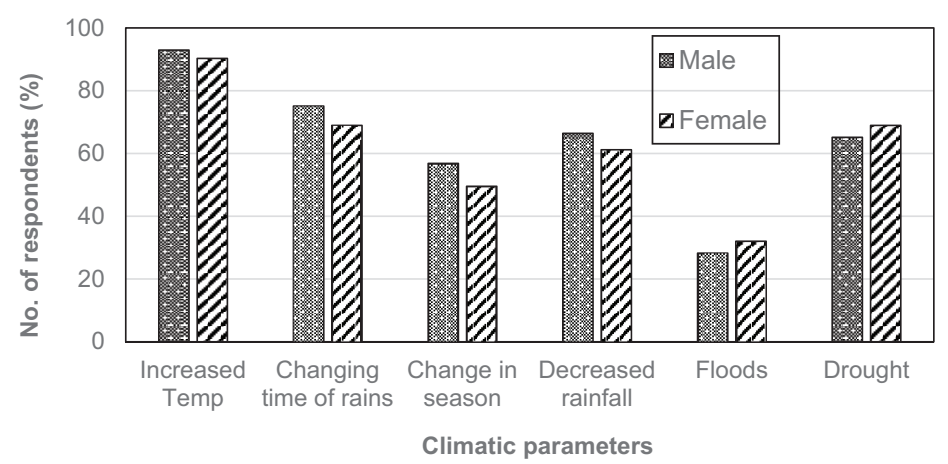

Figure 6.

Farmers' perception of extreme vulnerability to climate change in the Pra River Basin 
IJCCSM

$13,4 / 5$

\section{8}

\section{Figure 7.}

Cocoa farm near river Birim at Abomosu community farming communities. This observation is supported by a statement from a male farmer from Atiwa West district who could not pay back a loan secured to expand his farm due to flooding as he reported:

I took a loan from a bank in 2016 to expand my vegetable production during the lean (dry) season on a lowland near river Birim with a high expectation of greater yield. Unfortunately, the rains started a month earlier than I expected and took over the 2 acres' farm. My gain was the little I harvested for consumption before the unexpected rainfall. For the past three years, I have been struggling to pay back the loan to ask for more. I think this insecurity and risk is one major reason why the banks are refusing to give us loans.

The FGDs also revealed that after each flood event, farmers experienced reduced crop yields. The farmers also indicated that flooding introduced unknown plant diseases that affected some farms close to the rivers in the basin. Figure 7 shows a cocoa farm close to Birim River (in Abomosu community in the Atiwa West District of Ghana) that is flooded every year. The whole cocoa farm is sometimes submerged during flooding according to farmers. Based on the response from participants in the FGDs, the major cause of the floods was galamsey, which may cause siltation of the rivers and urbanization (building in waterways).

\subsection{Adaptation strategies adopted by farmers in response to climate change}

Adaptation strategies were limited to crop farming, particularly, crops and farming types in the basin.

3.4.1 Practised adaptation strategies. All respondents indicated that they have made more than one change on their farm to improve their agricultural yields. The first three most common adaptation strategies by women $(n=103)$ were the use of improved crop varieties $(98.1 \%)$, tree planting $(95.1 \%)$ and agrochemicals $(93.2 \%)$, whereas that of men $(n=241)$ were the use of agrochemicals $(97.5 \%)$, improved crop varieties $(96.7 \%)$ and tree planting $(95.4 \%)$ (Figure 8). Responses from extension officers on adaptation strategies aligned with

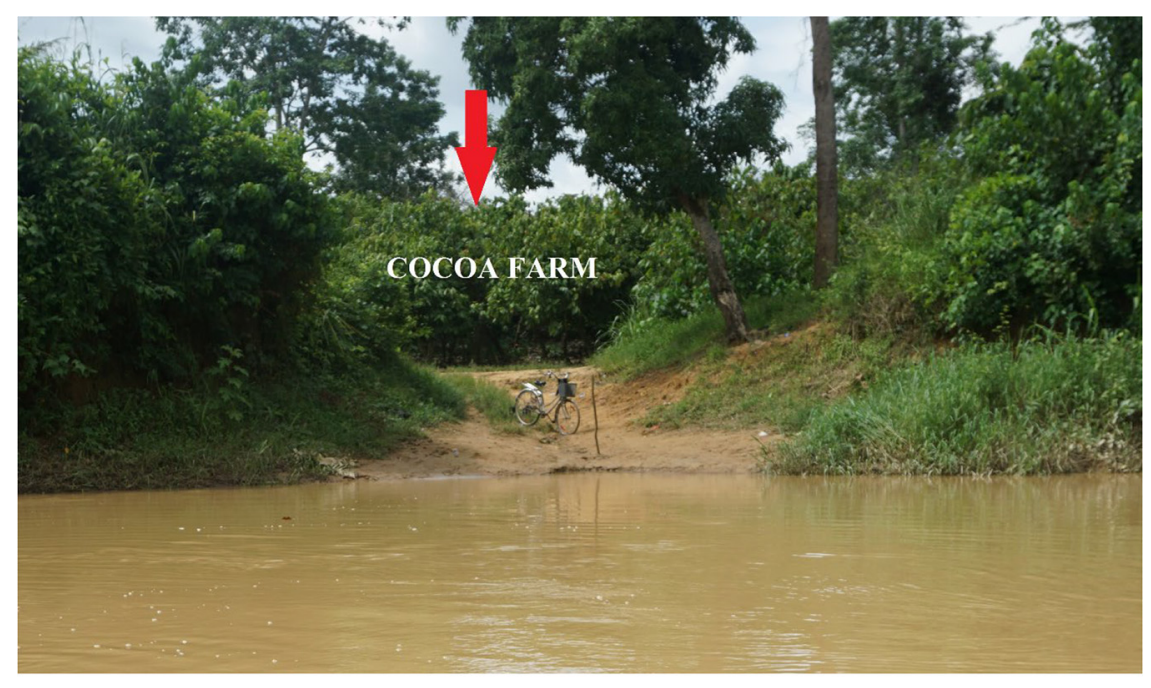

Note: The muddy colour of the river is intensified due to galamsey 


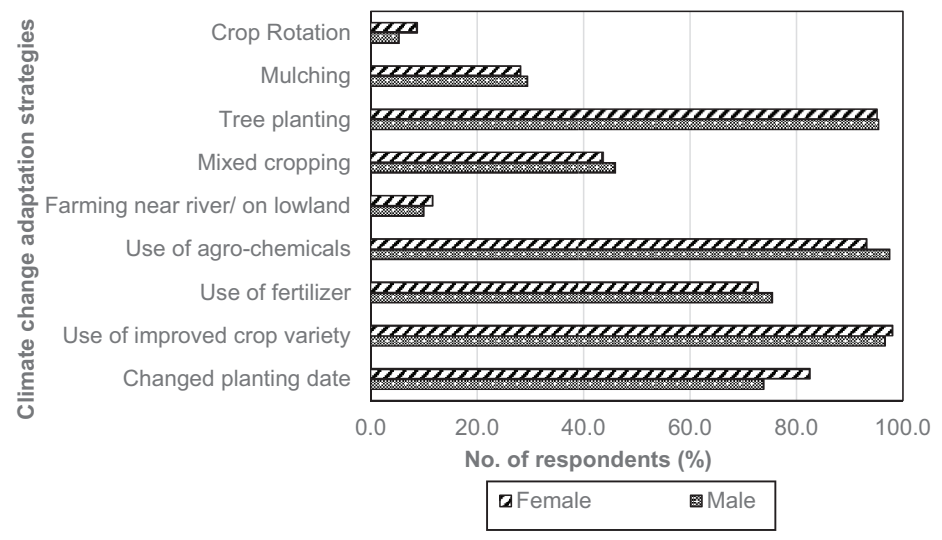

Perception of
climate change
impact

449

Figure 8.

Adaptation strategies of farmers to climate change in the Pra River Basin

that of farmers on the use of improved crop varieties, fertilizer usage, tree planting and changing of planting date on average. Future adaptation strategies suggested by the extension officers were: adoption of new agricultural technologies; shift to tree crops; engagement in climate-smart agriculture and diversification of agricultural activities.

Most of the farmers were willing to move their farms nearer to a river to have access to water for irrigation during the dry season but such locations are often difficult to secure for farming. The major reason was that crops produced during the dry season have high market value. It was noted that female farmers have, on average, more difficulty accessing lands near waterbodies, possibly due to a reduced or limited control they have over land resources and inadequate financial resources to secure farms in such locations in the Pra River basin. During our FGDs at Obuasi East district, a farmer reported based on his observation that floods from river Gyimi end around mid-October annually. To maximize the river for dry season production, he only prepares his land for vegetable production a week after mid-October every year. This strategy enables him to harvest his vegetables before flooding starts in the following year. It is worth noting that these locations close to rivers are mostly within the buffer zones (i.e. $50 \mathrm{~m}$ on both sides of rivers) protected by law. Farmers out of livelihood necessities cultivate in these unauthorized areas. Finding alternative livelihood intervention will help reduce the pressure on buffer zones and riverbank erosion.

Other climate change adaptation measures were no-tillage farming, cover cropping, rainwater harvesting on-farm and reduction of shade on crops by cutting some trees to increase crop access to sunlight. Additional adaptation strategies mentioned during the FGDs were dugouts (small wells) on farms, farming in different locations and reducing farm size. In the future, respondents perceive that measures such as early warning systems, irrigation facilities, shifting to organic farming, reducing farm size and the number of crop types planted in mixed cropping will enhance their adaptation.

3.4.2 Constraints to practised adaptation strategies. The three highest constraints for both male and female respondents were lack of access to credit, adaptation information, and water for irrigation (Table 3). While lack of information on adaptation, lack of access to water for irrigation were the second and third constraints for women, the reversal was observed for the male counterparts.

Farmers explained during the FGDs that access to credit will increase their financial capacity to purchase the required quantity of agrochemicals and fertilizers (Figure 8) to 
IJCCSM

$13,4 / 5$

450

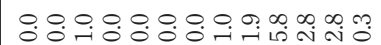

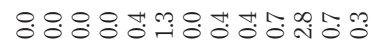

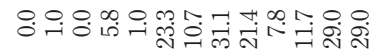

可证

离

艺零

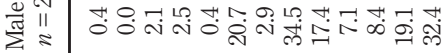



o

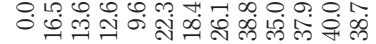$$
\text { . }
$$

零

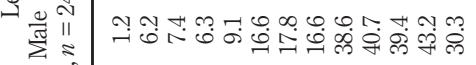

(1)

용

편

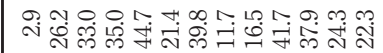

离

离

논

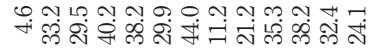

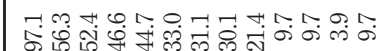

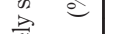

离寻

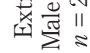

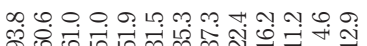
¿े

Table 3.

The severity of constraints to the adaptation of farmers to climate change in the Pra River Basin 


\begin{tabular}{|c|c|c|c|}
\hline External support & Male $(\%, n=241)$ & Female $(\%, n=103)$ & Perception of \\
\hline \multicolumn{4}{|l|}{ Type of support } \\
\hline Extension service & 81.7 & 67.0 & \\
\hline Trainings/workshop & 68.9 & 54.4 & \\
\hline Subsidized input & 42.7 & 39.8 & \\
\hline Weather info & 29.9 & 24.3 & \\
\hline Material & 6.6 & 8.7 & 451 \\
\hline Mass spraying & - & 1.9 & \\
\hline Financial & - & 1.0 & \\
\hline \multicolumn{4}{|l|}{ Source of support } \\
\hline Government & 86.3 & 84.5 & External support \\
\hline NGO's & 3.7 & 5.8 & received by farmers \\
\hline Community farmers' groups & 2.9 & 1.0 & to help in climate \\
\hline Cooperatives & 2.1 & 1.0 & change adaptation in \\
\hline Agricultural research stations & 0.8 & - & the Pra River Basin \\
\hline
\end{tabular}

control pests and disease and improve the fertility of the soils for increased yield. The lack of access to water for irrigation was often attributed to the degradation of water bodies by galamsey. Both farmers and extension officers admitted that extension services (i.e agronomical assistance) were inadequate due to a limited number of extension officers in the districts. For example, the extension officer at Twifo Ati-Morkwa has 13 communities (each of them with several farmers) under his operational area. Farmers did not consider land tenure to be a severe constraint because they can get land to rent for their work if they have the required amount in hand or access to credit.

3.4.3 External support for adaptation to climate change. The study showed that $88.8 \%$ and $85.4 \%$ of men and women, respectively, receive at least one type of support for their adaptation measures (Table 4). The four main supports were: extension service, training/ workshops, subsidized farm input and weather information. The mean period of this support ranged between 2 and 7 years. The most recent practice was the mass spraying of cocoa farms to control pests and diseases. Men benefited more from external support, with the exception of financial support (loans), all other supports were given to farmers for free. Extension, subsidized farm inputs, training and workshops were provided by the Government of Ghana through the Ministry of Food and Agriculture and Ghana Cocoa Board. However, subsidized inputs for non-cocoa farmers are recent (less than 3 years) although the supply has been irregular. Even though men benefited more from external support, the support from NGOs targeted more women than men to ensure that women are empowered to be more resilient to climate change impacts (Table 4). The external support was beneficial at different levels of $81.7 \%$ and $73.8 \%$ for men and women, respectively. The two main benefits from the external support were improved crop yields and reduced postharvest losses. Five out of the six extension officers indicated the same benefits and further stated that the support has improved the livelihood of farmers.

Despite the essential role of climate information services in adaptation, only $27.0 \%$ and $25.2 \%$ of men and women, respectively, receive information on rainfall and temperature from extension officers. Extension officers offer climate information upon request by a farmer during planting seasons. They can provide such information to farmers even if it is not required, particularly at the beginning of the planting season. They also explained that they retrieved information from the radio and television (TV) programmes, which are also 
IJCCSM

$13,4 / 5$

available to farmers. However, three $(n=6)$ of the extension officers have never provided climate information to farmers.

The main source of information that helps farmers in their adaptation was the radio (male $=94.6 \%$, female $=95.1 \%$ ). The second and third sources for both male and female was TV and other neighbouring farmers, as indicated by $35.7 \%$ and $26.2 \%$, respectively. Contemporary technology (internet, SMS, mobile apps and computer) was the least source of technical assistance due to the level of expertise required to operate them and the cost involved. However, this type of technology may be more locally accessible over time and likely to be more used by a younger generation of farmers. It was noticed that there is increased access to more affordable devices such as second-hand mobile phones and cheap devices among some local farmers.

\section{Discussion}

The socio-economic characteristics of respondents are in line with the report of the 2010 population and housing census report on farming households with the majority (that is 30 60 years) agreeing with the highest age group of the working class in agriculture between 15 and 64 years (GSS, 2013). The gender difference in educational level distribution was in line with the literacy level between men $(80 \%)$ and women $(69 \%)$ in Ghana (GSS, 2013), which could affect their perception of climate change impact and vulnerability (Owusu et al., 2018). Generally, women were less represented in the gatherings organized for the study and, hence, in the sampling locations all women were selected to participate. However, their representation was just about $30 \%$ for both questionnaire administration and FGDs. This could be due to the cultural norm that men are the heads of the family who are supposed to represent families in any gathering especially when both husband and wife are involved; a similar patriarchal behaviour was also observed in other studies (Nyantakyi-Frimpong and Bezner-Kerr, 2015; Ahmed et al., 2016; Rao et al., 2017). Besides, more men were educated and had access to both social amenities and better locations of the farm with access to rivers than women. The findings have shown that men that had more control of resources than women could influence the results towards other similar patterns of gender inequality observed elsewhere in Ghana (Fosu-Mensah et al., 2012; Wrigley-Asante et al., 2017; Owusu et al., 2018).

Respondents were mostly aware of climate change in the basin and radio was a major source of information to farmers in this study, analogous to the observed for other rural areas in different Sub-Saharan Africa countries (Ahmed et al., 2016; Sandstrom and Strapasson, 2017). Radio is easily accessible and a companion for farmers especially in rural areas. Although the past experience of respondents informed them of the changes in climate, the awareness from the radio, confirmed their observations. More men had easy access to information on climate change than women except information sourced from friends, family and neighbours. This suggests that women are more engaged with domestic responsibilities which partially limit their time to listen to the radio or watch TV, obtaining second-hand information from neighbours, friends and family.

The farmers consented that the severity of temperature increase in the basin for the past 20 years, which is in line with actual records obtained from local climatological stations from 1991-2014 for both maximum and minimum temperature. Temperature change has a direct effect on crop yield (Schleussner et al., 2018), water demand (Arnell, 2004) and labour capacity (Masuda et al., 2019), often resulting in reduced productivity and it can be easily felt. Farmers' observation of changes in rainfall pattern was contrary to the climate station records in the basin. Rainfall amount was perceived by both genders to be decreasing, onset to be late and cessation of rainfall to be early (Figure 3). Climate station records showed an 
increasing trend of rainfall amount, early onset and late cessation for the period 1991-2014 (Figure 4 and 5). The variation in results on rainfall could be attributed to the high spatial variability of rainfall distribution in the basin (Bessah et al., 2020a) and the factors influencing the trend of observed rainfall by farmers. Oyerinde et al. (2015) observed that perceptions of local people on climate change are influenced by both social and environmental factors, including their economic occupation. For instance, farmers that rate rainfall performance by productivity would tend to perceive a decreasing rainfall amount when a crop year does not yield up to expectation. Moreover, farmers perceive rainfall to have started (onset) when the amount is enough and continuous for the germination of their crops. This is different from factors such as minimum rainfall amount used by climate scientists to determine the onset and cessation of rainfall. For an appropriate assessment of rainfall from farmers' perspective, training would be necessary to improve their skills (Nyadzi et al., 2019; Diallo et al., 2020). The perception of farmers on rainfall onset, cessation and amount does not undermine their ability to forecast rainfall which according to studies on indigenous knowledge has been found to be effective (Mafongoya and Ajayi, 2017). More men observed a decreased rainfall amount and late-onset than women whereas more women perceived rainfall cessation dates to be early than men. This could be partially attributed to the gender roles in crop production where most men do land preparation, hence more concerned about onset while the women (either owned or hired labour) are more into farm maintenance until the crops are ready for harvest.

The variation in the perceived impact of climate change may also be associated with the gender roles in the production process and funding access. Prevalence of pest invasion, the rising cost of farm inputs and changes in onset and cessation of rainfall were the first three major impacts according to the men probably due to the immediate cost implication and linkages. Impact on livestock was not significant in this study because respondents reared livestock mostly for family use and not on a commercial scale. Farmers control pests' invasion with the use of agrochemicals. Hence, a higher prevalence of pest invasion will require large quantities of agrochemicals, which may also increase the cost. Farmers have observed that pest invasion is limited during the rainfall season. This is because the cold environment created by the rains is unfavourable for most pests that attack the crops in the basin. Therefore, the variation in rainfall coupled with the increasing temperature affects their farming activities. The topmost three impacts as perceived by the women in order were increased frequencies of drought and crop failure, changes in the onset and cessation of rainfall, and prevalence of pest invasion or the rising cost of farming inputs. On average, women were less involved in the use of agrochemicals equipment than men. Most women use hired labour who are men to apply agrochemicals to control pests and diseases on their farms. Female farmers with limited financial capacity may be unable to buy agrochemicals and hire labour to control pests and diseases. Such female farmers may resort to less capitalintensive agroecological measures to minimize the destruction caused by pests and diseases (Gliessman, 2014). As women are more involved in the maintenance of farms from seeding to harvesting, they can easily observe inter and intra seasonal droughts, dry spells and crop failure more than the men.

Agricultural production in Ghana is more susceptible to climate change which also renders many farmers who rely on the sector more vulnerable. More men are perceived to be vulnerable to temperature and rainfall events while more women felt more vulnerable to droughts and floods. Analogously, Arnell (2004) and Owusu et al. (2018) found that women are more vulnerable to water scarcity (drought) due to their usual gender roles in their household and farming activities in Africa. Women were more vulnerable to floods and drought because they lose more resources (food and income) during these climate events
Perception of climate change impact

453 
IJCCSM

$13,4 / 5$

(Codjoe et al., 2012), possibly because they have less access and support to adaptation measures than male farmers on average, as well as due to the less resilient locations of their farm to droughts as research has shown that properties closer to water bodies are mostly owned by men.

Male and female farmers adopted similar adaptation strategies for there appears to be a close relationship among respondents either at the family level or in farmers' association in the communities (Lawson et al., 2019). The adoption of improved crop variety has been found to correlate well with educational level (Dadi et al., 2005; Beyene and Kassie, 2015; Lemessa, 2017), however, this was not the case in this study.

Apart from limited access to formal education, women adopted improved crop variety more than men in the study areas. Improved crop varieties usually provide an immediate benefit in terms of agricultural yields, especially in developing countries with limited access to technology in rural areas (Thurow, 2010). Some varieties, for example, are more tolerant to droughts and pests than others, among other benefits obtained through plant breeding.

Agronomic adaptation practices have been found to be more common among Ghanaian farmers (Fosu-Mensah et al., 2012; Ahmed et al., 2016; Wrigley-Asante et al., 2017; Donkor et al., 2018). Farming in open areas as done in the basin exposes farmers to high temperatures (Masuda et al., 2019). This leads to the practice of social adaptation measures like shifting working hours too early morning and late afternoon as adopted by farmers in the study area. The high adoption of tree planting by farmers could result from the perceived increased temperature and the agronomic practices promoted by the Ministry of Agriculture (MoFA) (Orlove et al., 2010; Spence et al., 2011; MEST, 2012). Trees on farms reduce direct solar radiation on crops and farmers during their working hours in the day, and further control evapotranspiration (Bright et al., 2017; Ellison et al., 2017; Scott et al., 2018). Forest trees provide benefits such as shade during working hours, higher carbon sequestration and biodiversity conservation. The variation in the order of adaptation choice could also be linked to gender roles. The use of agrochemicals was the first choice for the men probably because of better access to resource control in comparison to their female counterparts (Fosu-Mensah et al., 2012; Owusu et al., 2018), followed by the use of improved crop variety and tree planting. Most men are now adapting their daily routine to avoid working on the farm during the hottest hours of the day, while women mostly arrive on the farm late after completing house chores, working during the hottest hours of the day to return home early in the evening to cater for their family. Therefore, tree planting would benefit women more than men because of the period of working hours. The three topmost adaptations for women in descending order were the use of improved crop variety, tree planting and use of agrochemicals. Based on the findings from the study, more women used improved crop variety than men which could be an indication that women in the basin adopt new agricultural practices more easily than men. None of the respondents was aware of crop insurance as an adaptation strategy despite the launching of the Drought Insurance Index (DII) in Ghana in 2008, although farmers in Northern Ghana were usually well informed and willing to pay for it (Abugri et al., 2017). Migration was not an apparent adaptation strategy in the area which could be attributed to the results obtained from other available adaptation strategies that may have increased production. Similar findings have been reported in Northern Ghana (Laube et al., 2012).

A major constraint to adaptation was the lack of access to credit by both genders, however, more women (97.1\%) lack access than men (93.8\%) (Fosu-Mensah et al., 2012). Farming is now expensive due to the rising cost of farm input such as improved crop varieties, fertilizer and agrochemicals plus the labour cost in the utilization of the input when the farmer is not skilled or has physical fitness to do so in cases like agrochemical 
spraying. The male dominance might be due to their resource control power entrenched in the culture and traditions of the area, while also keeping privileges and gender inequality in the region. This behaviour has also been commonly observed in Sub-Saharan Africa more broadly (Below et al., 2012; Fosu-Mensah et al., 2012; Owusu et al., 2017). In Northern Tanzania, for example, Sandstrom and Strapasson (2017) demonstrated that women usually have less access to agricultural assets (e.g. livestock, grazing lands, farm equipment and inputs such as fertilizers, seeds and agrochemicals) than men.

In the current study, lack of access to adaptation information was the second and third topmost constraint for women and men, respectively. The results imply that knowledge on how to use adaptation information is key to strategy adoption. The difference in rank of constraint could be due to the difference in the educational level of men and women, although a random variable is also a possibility. More men had access to education, which allows them to access or interpret adaptation information more easily. Therefore, there is a need for dedicated policies to increase female access to formal education to promote gender equality and climate resilience in the Pra River basin. Another reason could be the limited access of women to social/community gatherings where training and adaptation information is mostly transferred to the male farmers. Traditions and culture of the study areas, coupled with a potential gender prejudice or discrimination against women, played a key role in this limitation. Lack of access to water for irrigation was the second topmost constraint for men and third for women. Men engage more in irrigation farms using diesel pumps and polyvinyl chloride (PVC) pipes. Watering cans are used to irrigate young crops while farms are "flooded manually with pumps" when crops mature, as this method of irrigation required less time. The type of labour involved and unequal access to knowledge could explain why more men are involved. Illegal mining has polluted most of the surface water, rending it unfit for irrigation of crops. Farmers also perceived that the polluted water could affect the quality of crops produced. Some of the major challenges to gender equality in climate change vulnerability and adaptation that are of disadvantage to women were low literacy rates, unfavourable land tenure systems and limited access to resources for climate change adaptation (MEST, 2012).

Extension service is the highest form of adaptation support received by farmers. Through extension services, other supports like subsidized farm input and workshops are organized to train farmers. Generally, more men benefited from these supports than women probably due to the low literacy rate and limited resource control power of women, as well as potential gender discrimination. An affirmative action to increase female access to these technical supports and training would be beneficial, including employment of more female extension officers (e.g. agronomists). Besides, to help farmers improve their adaptation strategies, it is important that extensionists have a critical systems view, advanced knowledge and appropriate communication skills to have a horizontal and efficient dialogue with farmers, without sounding professorial, while also knowing the reality of local communities (Freire, 2002).

Regarding access to climate information, both gender groups had very low access (men = $29.9 \%$; women $=24.3 \%$ ) in the basin. Access to weather and climate forecast strengthens the preparedness of farmers to reduce risk (Sandstrom and Strapasson, 2017; Nyadzi et al., 2019). Moreover, extension officers had no linkage with weather and climate information service providers like Ghana Meteorological Agency, and limited knowledge and skill in climate information to interpret them to farmers. Both extension officers and farmers rely on the radio for weather and climate information. Farmers rely on their indigenous knowledge mainly and secondly on the radio to make a major decision about the climate in their farming activities. More women had access to material and financial support than men mainly because these supports were provided by NGOs and farmers cooperatives. The vision for women empowerment championed by NGOs could be the reason for women 
IJCCSM

$13,4 / 5$

benefiting more than men. Financial support from cooperatives was to be paid back without interest. Farmers cooperatives could contribute to improving access to credits, crop insurance and trade-in farming communities when supported by the government through the Ministry of Food and Agriculture and financial experts.

Regarding water management in the Pra River Basin, major efforts to improve water quality are clearly necessary, given that some polluted rivers in the basin, affected by galamsey and precarious sanitation in some areas, have been impacting not only agriculture and climate change resilience but also human health. Similar conditions have been observed in other SubSaharan African countries. In Senegal, for example, Manikowski and Strapasson (2016) demonstrated that the construction of a water dam in the Senegal River has caused major impacts on human health and plant diseases across the river valley, due to unappropriated construction planning and policy. Therefore, investments for improving water management and infrastructure in the Pra River Basin need to be carefully addressed to avoid further impact, particularly, due to the projected decrease in water availability in the basin (Bessah et al., 2020b). The participation of local communities in the decision-making process, with special attention to gender balance, is fundamental for promoting sustainable development and climate resilience in the region, given that they are directly affected by any changes in the river basin.

\section{Conclusion}

This study demonstrated that gender plays a significant role in the perception of climate change impact, vulnerability and adaptation and that they are influenced by different responsibilities, traditions and cultural norms. It was observed that women are often restricted from social gatherings which discriminate them in their capacity to be informed and participate in the decision-making process possibly due to the patriarchal culture in the study area. Women had less access to social amenities which made them more vulnerable to manifested climate change impacts such as floods and drought compared to their male counterparts. Moreover, women adopted strategies that have to do with consistent observation of change such as varying planting dates and changing crop variety, while the men resorted to adaptation such as the use of agrochemicals in farming. Several adaptation strategies practiced in the basin are capital intensive, therefore, lack of access to credit was an overarching challenge to the sustainability of the approach. Finally, farmers' cooperatives and Civil Society Organizations (CSOs), as well as dedicated public policies could contribute to reaching gender equality in the region regarding climate change and agricultural development through women empowerment programmes and affirmative actions to improve the level of resource control by women in the basin. Future research should focus on complementary issues, which will build on findings from this study such as:

- to evaluate the interrelationship between physical parameters and climatic change parameters;

- to provide detailed information on groundwater components in relation to seepage from the Pra River Basin; and

- to assess variations in rainfall intensities in the basin.

\section{Note}

1. Twi is the local language of most of the Akan ethnic group in Ghana. They are the major ethnic group covering most of the southern and central part of Ghana. There are different types of Twi depending on the specific tribe in the Akan ethnic group one belongs. The study used the Asante Twi for interviewing farmers. 


\section{References}

Abugri, S., Amikuzuno, A.J. and Daadi, E.B. (2017), "Looking out for a better mitigation strategy: smallholder farmers' willingness to pay for drought-index crop insurance premium in the Northern region of Ghana”, Agriculture and Food Security, Vol. 6 No. 1, doi: 10.1186/s40066-017-01522.

Perception of climate change impact

Alhassan, S.I., Kuwornu, J.K.M. and Osei-Asare, Y.B. (2019), "Gender dimension of vulnerability to climate change and variability: empirical evidence of smallholder farming households in Ghana", International Journal of Climate Change Strategies and Management, Vol. 11 No. 2, pp. 195-214, doi: 10.1108/IJCCSM-10-2016-0156.

Arnell, N.W. (2004), "Climate change and global water resources: SRES emissions and socioeconomic scenarios”, Global Environmental Change, Vol. 14 No. 1, pp. 31-52, doi: 10.1016/ j.gloenvcha.2003.10.006.

Below, T.B., Mutabazi, K.D., Kirschke, D., Franke, C., Sieber, S., Siebert, R. and Tscherning, K. (2012), "Can farmers' adaptation to climate change be explained by socio-economic household-level variables?”, Global Environmental Change, Vol. 22 No. 1, pp. 223-235, doi: 10.1016/j. gloenvcha.2011.11.012.

Bessah, E., Raji, A.O., Taiwo, O.J., Agodzo, S.K. and Ololade, O.O. (2018), "Variable resolution modeling of near future mean temperature changes in the dry sub-humid region of Ghana", Modeling Earth Systems and Environment, Vol. 4 No. 3, pp. 919-933, doi: 10.1007/s40808018-0479-0.

Bessah, E., Raji, A.O., Taiwo, O.J., Agodzo, S.K. and Ololade, O.O. (2020a), "The impact of varying spatial resolution of climate models on future rainfall simulations in the pra river basin (Ghana)", Journal of Water and Climate Change, Vol. 11 No. 4, doi: 10.2166/wcc.2019.258.

Bessah, E., Raji, A.O., Taiwo, O.J., Agodzo, S.K., Ololade, O.O. and Strapasson, A. (2020b), "Hydrological impacts of climate and land use changes: the paradox of regional and local climate effect in the pra river basin of Ghana", Journal of Hydrology: Regional Studies, Vol. 27, p. 100654, doi: 10.1016/ j.ejrh.2019.100654.

Beyene, A.D. and Kassie, M. (2015), "Speed of adoption of improved maize varieties in Tanzania: an application of duration analysis", Technological Forecasting and Social Change, Vol. 96, pp. 298307, doi: 10.1016/j.techfore.2015.04.007.

Bright, R.M., Davin, E., O’Halloran, T., Pongratz, J., Zhao, K. and Cescatti, A. (2017), “Local temperature response to land cover and management change driven by non-radiative processes", Nature Climate Change, Vol. 7 No. 4, pp. 296-302, doi: 10.1038/nclimate3250.

Chandio, A.A., Jiang, Y., Rehman, A. and Rauf, A. (2020), "Short and long-run impacts of climate change on agriculture: an empirical evidence from China", International Journal of Climate Change Strategies and Management, Vol. 12 No. 2, pp. 201-221, doi: 10.1108/IJCCSM-05-20190026.

Chauvin, N.D., Mulangu, F. and Porto, G. (2012), "Food production and consumption trends in SubSaharan Africa: prospects for the transformation of the agricultural sector", united nations development programme (UNDP)", Regional Bureau for Africa, Working paper, wp 2012-011, p. 76.

Chhogyel, N. and Kumar, L. (2018), "Climate change and potential impacts on agriculture in Bhutan: a discussion of pertinent issues”, Agriculture and Food Security, Vol. 7 No. 1, doi: 10.1186/s40066018-0229-6.

Codjoe, S.N.A., Atidoh, L.K. and Burkett, V. (2012), "Gender and occupational perspectives on adaptation to climate extremes in the Afram plains of Ghana", Climatic Change, Vol. 110 Nos 1/2, pp. 431-454, doi: 10.1007/s10584-011-0237-z. 
IJCCSM $13,4 / 5$

Dadi, L., Burton, M. and Ozanne, A. (2005), "Duration analysis of technological adoption in Ethiopian agriculture", Journal of Agricultural Economics, Vol. 55 No. 3, pp. 613-631, doi: 10.1111/j.14779552.2004.tb00117.x.

Denton, F. (2002), “Climate change vulnerability, impacts, and adaptation: why does gender matter?", Gender and Development, Vol. 10 No. 2, pp. 10-20, doi: 10.1080/13552070215903.

Diallo, A., Donkor, E. and Owusu, V. (2020), "Climate change adaptation strategies, productivity and sustainable food security in Southern Mali", Climatic Change, Vol. 159 No. 3, pp. 309-327, doi: 10.1007/s10584-020-02684-8.

Dickson, K.B. and Benneh, G. (1995), A New Geography of Ghana, Longmans Book Comp.

Donkor, E., Owusu, V., Owusu-Sekyere, E. and Ogundeji, A.A. (2018), "The adoption of farm innovations among rice producers in Northern Ghana: implications for sustainable rice supply", Agriculture, Vol. 8 No. 8, doi: 10.3390/agriculture8080121.

Ellison, D., Morris, C.E., Locatelli, B., Sheil, D., Cohen, J., Murdiyarso, D., Gutierrez, V., van Noordwijk, M., Creed, I.F., Pokorny, J., Gaveau, D., Spracklen, D.V., Tobella, A.B., Ilstedt, U., Teuling, A.J., Gebrehiwot, S.G., Sands, D.C., Muys, B., Verbist, B., Springgay, E., Sugandi, Y. and Sullivan, C.A. (2017), "Trees, forests and water: cool insights for a hot world", Global Environmental Change, Vol. 43, pp. 51-61, doi: 10.1016/j.gloenvcha.2017.01.002.

Fagariba, C.J., Song, S. and Soule Baoro, S.K.G. (2018), "Climate change adaptation strategies and constraints in Northern Ghana: evidence of farmers in Sissala west district", Sustainability, Vol. 10 No. 5, doi: 10.3390/su10051484.

Fosu-Mensah, B.Y., Vlek, P.L. and MacCarthy, D.S. (2012), "Farmers' perception and adaptation to climate change: a case study of Sekyedumase district in Ghana", Environment, Development and Sustainability, Vol. 14 No. 4, pp. 495-505, doi: 10.1007/s10668-012-9339-7.

Freire, P. (2002), Extensão ou Comunicação (Extension or Communication), Original version in Portuguese language. Paz e Terra publishing house, Sao Paulo, Brazil, p. 93.

Garg, T., Jagnani, M. and Taraz, V. (2018), Temperature and Human Capital in India, SSRN. 10.2139/ ssrn.2941049.

Gasparrini, A., Guo, Y., Sera, F., Vicedo-Cabrera, A.M., Tong, S., Coelho, M.S.Z.S., Saldiva, P.H.N., Lavigne, E., Correa, P.M., Ortega, N.V., Kan, H., Osorio, S., Kyselý, V., Urban, A., Jaakkola, J.J.K., Ryti, N.R.I., Pascal, M., Goodman, P.G., Zeka, A., Michelozzi, P., Scortichini, M., Hashizume, M., Honda, Y., Hurtado-Diaz, M., Cruz, J.C., Seposo, X., Kim, H., Tobias, A., Iñiguez, V., Forsberg, B., Åström, D.O., Ragettli, M.S., Guo, Y.L., Wu, C.-f., Zanobetti, A., Schwartz, J., Bell, M.L., Dang, T. N., Van, D.D., Heaviside, C., Vardoulakis, S., Hajat, S., Haines, A. and Armstrong, B. (2017), "Projections of temperature-related excess mortality under climate change scenarios", The Lancet Planetary Health, Vol. 1 No. 9, pp. e360-e367, doi: 10.1016/S2542-5196(17)30156-0.

Glenn, I.D. (1992), Sampling the Evidence of Extension Program Impact, Program Evaluation and Organizational Development (IFAS), University of FL.

Gliessman, S.R. (2014), Agroecology: The Ecology of Sustainable Food Systems, CRC press (Taylor and Francis Group), 3rd ed., p. 405.

GSS (2013), 2010 Population and Housing Census Report: women and Men in Ghana, Government of Ghana.

Hooks, B. (2014), Feminism is for Everybody, 2nd ed., Routledge, p. 138.

Hsiang, S.M. and Sobel, A.H. (2016), "Potentially extreme population displacement and concentration in the tropics under non-extreme warming", Scientific Reports, Vol. 6 No. 1, pp. 4-10, doi: 10.1038/srep25697.

IFPRI (2010), "Irrigating Africa”, International Food Policy Research Institute (IFPRI), available at: www.ifpri.org/blog/irrigating-africa (accessed 12 August 2019).

IPCC (2007), "Summary for policymakers", in Solomon, S., Qin, D., Manning, M., Chen, Z., Marquis, M., Averyt, K.B., Tignor, M. and Miller, H.L. (Eds), Climate Change 2007: The Physical Science Basis. Contribution of Working Group I to the Fourth Assessment Report of the Intergovernmental Panel on Climate Change, Cambridge University Press, pp. 1-18. 
IPCC (2014), Climate Change 2014: Synthesis Report. Contribution of Working Groups I, II and III to the Fifth Assessment Report of the Intergovernmental Panel on Climate Change, Core Writing Team, in Pachauri, R.K. and Meyer, L.A. (Eds), IPCC, p. 169.

Kusimi, J.M., Yiran, G.A.B. and Attua, E.M. (2015), "Soil erosion and sediment yield modelling in the pra river basin of Ghana using the revised universal soil loss equation (RUSLE)", Ghana Journal of Geography, Vol. 7 No. 2, pp. 38-57.

Laube, W., Schraven, B. and Awo, M. (2012), "Smallholder adaptation to climate change: dynamics and limits in Northern Ghana”, Climatic Change, Vol. 111 Nos 3/4, pp. 753-774, doi: 10.1007/s10584011-0199-1.

Lawson, E.T., Alare, R.S., Salifu, A.R.Z. and Thompson-Hall, M. (2019), "Dealing with climate change in semi-arid Ghana: understanding intersectional perceptions and adaptation strategies of women farmers”, GeoJournal, doi: 10.1007/s10708-019-09974-4.

Lemessa, S.D. (2017), "A duration model for the investigation of the adoption spell of improved maize varieties in Ethiopia", International Journal of Sustainable Agricultural Management and Informatics, Vol. 3 No. 2, pp. 154-169, doi: 10.1504/IJSAMI.2017.085672.

Lobell, D.B., Burke, M.B., Tebaldi, C., Mastrandrea, M.D., Falcon, W.P. and Naylor, R.L. (2008), "Prioritizing climate change adaptation needs for food security in 2030", Science, Vol. 319 No. 5863, pp. 607-610, doi: 10.1126/science.1152339.

Mafongoya, P.L. and Ajayi, O.C. (2017), Indigenous Knowledge Systems and Climate Change Management in Africa, CTA, Wageningen.

Manikowski, S. and Strapasson, A. (2016), "Sustainability assessment of large irrigation dams in Senegal: a cost-benefit analysis for the Senegal river valley", Frontiers in Environmental Science, Vol. 4 No. 18, pp. 1-16, doi: 10.3389/fenvs.2016.00018.

Manoranjitham, S. and Jacob, S.K. (2007), "Focus group discussion”, Nursing Journal of India, Vol. 98 No. 6, pp. 125-127.

Masuda, Y.J., Castro, B., Aggraeni, I., Wolff, N.H., Ebi, K., Garg, T., Game, E.T., Krenz, J. and Spector, J. (2019), "How are healthy, working populations affected by increasing temperatures in the tropics? Implications for climate change adaptation policies", Global Environmental Change, Vol. 56, pp. 29-40, doi: 10.1016/j.gloenvcha.2019.03.005.

MEST (2012), Ghana National Climate Change Policy (NCCP), Ministry of Environment, Science and Technology, p. 87.

MoFA (2017), Planting for Food and Jobs, Strategic Plan for Implementation (2017-2020), Ministry of Food and Agriculture (MoFA), Republic of Ghana, p. 79.

Niang, I., Ruppel, O.C., Abdrabo, M.A., Essel, A., Lennard, C., Padgham, J. and Urquhart, P., (2014), "Africa", in Barros, V.R., Field, C.B., Dokken, D.J., Mastrandrea, M.D., Mach, K.J., Bilir, T.E., Chatterjee, M., Ebi, K.L., Estrada, Y.O., Genova, R.C., Girma, B., Kissel, E.S., Levy, A.N., MacCracken, S., Mastrandrea, P.R., and White, L.L. (Eds), Climate Change 2014: Impacts, Adaptation, and Vulnerability. Part B: Regional Aspects. Contribution of Working Group II to the Fifth Assessment Report of the Intergovernmental Panel on Climate Change, Cambridge University Press, pp. 1199-1265.

New, M., Hewitson, B., Stephenson, D.B., Tsiga, A., Kruger, A., Manhique, A., Gomez, B., Coelho, C.A.S., Masisi, D.N., Kululanga, E., Mbambalala, E., Adesina, F., Saleh, H., Kanyanga, J., Adosi, J., Bulane, L., Fortunata, L., Mdoka, M.L. and Lajoie, R. (2006), "Evidence of trends in daily climate extremes over Southern and West Africa", Journal of Geophysical Research, Vol. 111 No. D14, pp. 1-11, doi: 10.1029/2005JD006289.

Nutsukpo, D.K., Jalloh, A., Zougmoré, R., Nelson, G.C. and Thomas, T.S. (2013), “Ghana”, West African Agriculture and Climate Change: A Comprehensive Analysis, International Food Policy Research Institute, pp. 141-172, available at: http://ebrary.ifpri.org/cdm/ref/collection/p15738coll2/id/ 127450 (accessed 3 January 2018). 
IJCCSM $13,4 / 5$

Nyadzi, E., Werners, E.S., Biesbroek, R., Long, P.H., Franssen, W. and Ludwig, F. (2019), "Verification of seasonal climate forecast toward hydroclimatic information needs of rice farmers in Northern Ghana”, Weather, Climate, and Society, Vol. 11 No. 1, pp. 127-142, doi: 10.1175/WCAS-D-170137.1.

Nyantakyi-Frimpong, H. and Bezner-Kerr, R. (2015), "The relative importance of climate change in the context of multiple stressors in semi-arid Ghana", Global Environmental Change, Vol. 32, pp. 40-56, doi: 10.1016/j.gloenvcha.2015.03.003.

Ojo, T.O. and Baiyegunhi, L.J.S. (2020), "Determinants of climate change adaptation strategies and its impacts on the net farm income of rice farmers in South-west Nigeria”, Land Use Policy, Vol. 95, p. 103946, doi: 10.1016/j.landusepol.2016.04.007.

Ololade, O.O. and Rametse, P.P. (2018), "Determining factors that enable managers to implement an environmental management system for sustainable construction: a case study in Johannesburg", Business Strategy and the Environment, Vol. 27 No. 8, pp. 1720-1732, doi: 10.1002/bse.2237.

Orlove, B., Roncoli, C., Kabugo, M. and Majugu, A. (2010), "Indigenous climate knowledge in Southern Uganda: the multiple components of a dynamic regional system", Climatic Change, Vol. 100 No. 2, pp. 243-265, doi: 10.1007/s10584-009-9586-2.

Owusu, M., Nursey-Bray, M. and Rudd, D. (2018), "Gendered perception and vulnerability to climate change in urban slum communities in Accra, Ghana", Regional Environmental Change, doi: 10.1007/s10113-018-1357-z.

Owusu, V., Donkor, E. and Owusu-Sekyere, E. (2017), "Accounting for the gender technology gap amongst smallholder rice farmers in Northern Ghana", Journal of Agricultural Economics, Vol. 69 No. 2, pp. 439-457, doi: 10.1111/1477-9552.12236.

Oyerinde, G.T., Hountondji, F.C.C., Wisser, D., Diekkruger, B., Lawin, A.E., Odofin, A.J. and Afouda, A. (2015), "Hydro-climatic changes in the Niger basin and consistency of local perceptions", Regional Environmental Change, Vol. 15 No. 8, pp. 1627-1637, doi: 10.1007/ s10113-014-0716-7.

Rao, N., Lawson, E.T., Raditloaneng, W.N., Solomon, D. and Angula, M.N. (2017), "Gendered vulnerabilities to climate change: insights from the semi-arid regions of Africa and Asia", Climate and Development, doi: 10.1080/17565529.2017.1372266.

Sandstrom, S. and Strapasson, A. (2017), "Socio-Environmental assessment of gender equality, pastoralism, agriculture and climate information in rural communities of Northern Tanzania", Journal of Gender, Agriculture and Food Security, Vol. 2 No. 3, pp. 66-83, doi: 10.19268/ JGAFS.232017.4.

Schleussner, C.F., Deryng, D., Muller, C., Elliot, J., Saeed, F., Folberth, C., Liu, W., Wang, X., Pugh, T.A. M., Thiery, W., Senevirante, S.I. and Rogelj, J. (2018), "Crop productivity changes in 1.5 and 2 worlds under climate sensitivity uncertainty", Environmental Research Letters, Vol. 13 No. 6, p. 064007.

Scott, C.E., Monks, S.A., Spracklen, D.V., Arnold, S.R., Forster, P.M., Rap, A., Äijälä, M., Artaxo, P., Carslaw, K.S., Chipperfield, M.P., Ehn, M., Gilardoni, S., Heikkinen, L., Kulmala, M., Petäjä, T., Reddington, C.L.S., Rizzo, L.V., Swietlicki, E., Vignati, E. and Wilson, C. (2018), "Impact on short-lived climate forcers increases projected warming due to deforestation", Nature. Communication, Vol. 9, pp. 1-9, doi: 10.1038/s41467-017-02412-4.

Shikuku, K.M., Winowiecki, L., Twyman, J., Eitzinger, A., Perez, J.G., Mwongera, C. and Läderach, P. (2017), "Smallholder farmers' attitudes and determinants of adaptation to climate risks in east Africa”, Climate Risk Management, Vol. 16, pp. 234-245, doi: 10.1016/j.crm.2017.03.001.

Singh, A.S. and Masuku, M.B. (2014), "Sampling techniques and determination of sample size in applied statistics research: an overview", International Journal of Economics, Commerce and Management, Vol. 2 No. 11, pp. 1-22. 
Spence, A., Poortinga, W., Butler, C. and Pidgeon, N.F. (2011), "Perceptions of climate change and willingness to save energy related to flood experience", Nature Climate Change, Vol. 1 No. 1, pp. 46-49, doi: 10.1038/nclimate1059.

Thurow, R. (2010), Enough: Why the World's Poorest Starve in an Age of Plenty, Public Affairs (publisher), p. 336.

Traore, O., Chang, W., Rehman, A., Traore, S. and Rauf, A. (2020), "Climate disturbance impact assessment in West Africa: evidence from field survey and satellite imagery analysis", Environmental Science and Pollution Research, Vol. 27 No. 21, pp. 26315-26331, doi: 10.1007/ climate change impact s11356-020-08757-6.

UNDP (2010), Gender, Climate Change and Community-Based Adaptation, UNDP, New York, NY.

UNDP (2011), Ensuring Gender Equity in Climate Change Financing, UNDP, New York, NY.

WHO (2011), Gender, Climate Change and Health, World Health Organisation.

Wossen, T., Berger, T., Haile, M.G. and Troost, C. (2018), "Impacts of climate variability and food price volatility on household income and food security of farm households in east and west Africa", Agricultural Systems, Vol. 163, pp. 7-15, doi: 10.1016/j.agsy.2017.02.006.

WRC (2012), Pra River Basin - Integrated Water Resources Management Plan, Water Resources Commission (WRC), p. 53.

Wrigley-Asante, C., Owusu, K., Egyir, I.S. and Owiyo, T.M. (2017), "Gender dimensions of climate change adaptation practices: the experiences of smallholder crop farmers in the transition zone of Ghana”, African Geographical Review, Vol. 38 No. 2, doi: 10.1080/19376812.2017.1340168.

Xu, X., Hu, H., Tan, Y., Yang, G., Zhu, P. and Jiang, B. (2019), "Quantifying the impacts of climate variability and human interventions on crop production and food security in the Yangtze river basin, China, 1990 - 2015”, Science of the Total Environment, Vol. 665, pp. 379-389, doi: 10.1016/j. scitotenv.2019.118.

Yadav, S.S. and Lal, R. (2018), "Vulnerability of women to climate change in arid and semi-arid regions: the case of India and South Asia”, Journal of Arid Environments, Vol. 149, pp. 4-17, doi: 10.1016/j. jaridenv.2017.08.001.

Yamane, T. (1967), Statistics: An Introductory Analysis, Harper and Row.

\section{Further reading}

Lee, M., Villaruel, M.L. and Gaspar, R.E. (2016), "Effects of temperature shocks on economic growth and welfare in Asia”, ADB Economics, Vol. 501, pp. 1-41, doi: 10.2139/ssrn.2894767. WPS168568-2.

Nyuor, B.A., Donkor, E., Aidoo, R., Saaka Buah, S., Naab, J.B., Nutsugah, S.K., Bayala, J. and Zougmoré, R. (2016), "Economic impacts of climate change on cereal production: implications for sustainable agriculture in Northern Ghana", Sustainability, Vol. 8 No. 8, p. 724, doi: 10.3390/ su8080724.

\section{Corresponding author}

Enoch Bessah can be contacted at: enoch.bessah@gmail.com

\section{Author affiliations}

Enoch Bessah, Department of Agricultural and Biosystems Engineering, Kwame Nkrumah University of Science and Technology, Kumasi, Ghana, and Pan African University Institute of Life and Earth Sciences (Including Health and Agriculture) University of Ibadan, Ibadan, Nigeria

AbdulGaniy Olayinka Raji, Department of Agricultural and Environmental Engineering, University of Ibadan, Ibadan, Nigeria

Olalekan John Taiwo, Department of Geography, University of Ibadan, Ibadan, Nigeria 
IJCCSM

$13,4 / 5$

462

Sampson Kwaku Agodzo, Department of Agricultural and Biosystems Engineering, Kwame Nkrumah University of Science and Technology, Kumasi, Ghana

Olusola Oluwayemisi Ololade, Centre for Environmental Management, University of the Free State, Bloemfontein, South Africa

Alexandre Strapasson, Belfer Center for Science and International Affairs, Harvard University, Cambridge, Massachusetts, USA and Centre for Environmental Policy, Imperial College London, London, UK

Emmanuel Donkor, Agrifood Management Group, Albrecht Daniel Thaer-Institute of Agricultural and Horticultural Sciences, Humboldt University of Berlin, Berlin, Germany

For instructions on how to order reprints of this article, please visit our website: www.emeraldgrouppublishing.com/licensing/reprints.htm

Or contact us for further details: permissions@emeraldinsight.com 